\title{
Late Complication of Knee Trauma: Isolated Common Peroneal Nerve Palsy
}

\author{
Diz Travmasının Geç Komplikasyonu: Izole Ana Peroneal Sinir Arazı
}

Mehmet Erdil, Hasan Hüseyin Ceylan, Mehmet Elmadağ, Kerem Bilsel, İbrahim Tuncay

Department of Orthopedics and Traumatology, Faculty of Medicine, Bezmialem Vakif University, İstanbul, Turkey

\section{ABSTRACT}

Introduction: Direct blunt or strain type traumas around the knee joint are not uncommon. In addition to osseous pathologies, soft tissue examination should be done meticulously. Otherwise additional problems may be neglected.

Case Report: We evaluated two patients who presented with knee trauma. In emergency conditions no pathologies were detected apart from knee pain. A few days later, both, these patients presented with footdrop. After physiotherapy and bracing, one of the patient recovered totally but the second one did not.

Conclusion: Common peroneal nerve traction or complete transection may result infootdrop. Patients must be informed by physicians about potential neurovascular problems.

Keywords: Peroneal nerve, knee trauma, footdrop

Received: 12.06.2012 Accepted: 22.10.2012

\section{ÖZET}

Giriş: Diz eklemi çevresinin künt ve traksiyon tipi travmaları sık karşılaşılan diz yaralanmalarıdır. Diz eklemi muayenesinde osseöz patolojilere ek olarak tüm yapıların muayenesi dikkatlice yapılmaIıdır. Aksi takdirde ek patolojiler atlanabilir.

Olgu Sunumu: Çalışmamızda acil servisimize diz travması ile başvuran iki hasta incelendi. Hastaların acil muayenesinde diz ağrısı haricinde herhangi bir patoloji saptanmazken, takip eden günlerde her iki hasta da düşük ayak kliniği ile başvurdular. Hastalara fizyoterapi ve breys tedavisi uygulandı. Aynı tedaviye bir hastamız tam cevap verirken diğer hastanın düşük ayak kliniği düzelmedi.

Sonuç: Ana peroneal sinirin gerilme ya da kesilme gibi travmaları düşük ayak kliniği ile sonuçlanabilmektedir. Hekim hastasını gelişebilecek olası nörovasküler komplikasyonlar açısından bilgilendirmelidir.

Anahtar Kelimeler: Peroneal sinir, diz travması, düşük ayak

Geliş Tarihi: 12.06.2012 Kabul Tarihi: 22.10.2012

\section{Giriş}

Diz travması sonrası izole peroneal sinir arazı pratikte sık karşılaşı Imayan bir durumdur (1, 2). Acil hekimi hastanın fizik muayenesi sonrasında x-ray incelemelerini değerlendirirken osseoz bir patolojiye odaklanıp yumuşak doku travmasını inmal edebilmektedir. Bu tür vakalarda diz yumuşak doku travması nedeniyle gelişebilecek peroneal sinir hasarı konusunda dikkatli olunmalıdır.

Bu çalışmamızda acil ortopedi servisimize başvuran iki hasta ele alındı. Başvuru anında herhangi bir osseöz ya da nörovaskuler problem saptanmayan hastalar, birkaç gün sonra düşük ayak gelişmiş şekilde tekrar kliniğimize başvurdular. Travma sonrası radyolojik incelemede osseöz patolojilerin varlığı değerlendirilirken eş zamanlı olarak çevre yumuşak dokuların uğradığı travma da göz ardı edilmemelidir. Olası komplikasyonlar akılda tutulmalı ve hasta bilgilendirilmelidir.

\section{Olgu Sunumları}

Bu çalışmada sunulacak her iki olguda da verilerin bilimsel sunum haline getirileceği belirtilmiş ve hastalardan onam alınmışır. 


\section{Olgu 1}

On altı yaşında erkek hasta diz üzerine aldığı künt travma sonrası gelişen aşırı diz ağrısı şikayeti nedeniyle yakınları tarafından acile getirildi. Yapılan fizik muayenesinde diz çevresindeki hafif ödem haricinde herhangi bir nörovasküler patoloji saptanamadı. Diz ekleminde ve tüm alt ekstremitede kırık belirtisi olacak herhangi bir dizilim kusuru yoktu. Radyolojik incelemede de osseöz patoloji saptanamayan hasta analjezik antienflamatuar tedavisi düzenlenerek taburcu edildi. Hasta üç gün sonra ayağını kaldıramama şikâyetiyle tekrar başvurdu. Muayenesinde ayak dorsifleksiyonu ve eversiyonunun total olarak kaybı saptandı. Duyu kusuru olmayan ayak peroneal sinir inervasyon alanında total motor kayıp mevcuttu. Yapılan elektromiyografi (EMG) incelemede ana peroneal sinir distalini etkileyen aksonal hasar saptandı. Hastamıza, ayak bileği fleksiyon kontraktürüne engel olmak için hemen ayak-ayakbileği ortezi uygulandı. Fizyoterapi ünitemizde elektrostimülasyon ve pasif egzersiz fizyoterapisi başlandı.

\section{Olgu 2}

Otuz altı yaşında erkek hasta iş yerinde ağır bir kütlenin dizine çarpması sonrası aşırı diz ağrısı şikâyetiyle arkadaşları tarafından acil servisimize getirildi. Diz medialine aldığı darbe sonucu varus tipi travma mekanizması tarifleyen hastamızın diz ağrısı haricinde herhangi bir şikayeti yoktu. Fizik muayenesi eklem çevresi şişlikten başka özellik yoktu. Nörovasküler muayenesi tamamen normaldi. Radyolojik incelemesinde özellik saptanmayan hasta analjezikle ve istirahat önerisiyle taburcu edildi (Resim 1). Bir hafta sonra poliklinik kontrolüne gelen hastada düşük ayak saptandı (Resim 2a, b). Yapılan Manyetik Rezonans (MR) incelemede peroneal sinir devamlılığının korunduğu fakat sinir kılıfı çevresinde belirgin ödem olduğu saptandı. Hastamıza hemen ayak-ayak bileği ortezi uygulandı ve elektrostimülasyon ile pasif egzersiz fizyoterapisi başlandı.

Illk olgumuzun konservatif takip ve düzenli şekilde uygulanan fizyoterapiye cevabı iyiydi. İkinci ayın sonunda peroneal fonksiyonları dönen hastanın yedi ay sonra ayak hareketleri total olarak normale döndü. EMG inceleme ile peroneal sinirin tamamen iyileştiği teyit edildi. Hasta günlük yaşamına geri döndü.

İkinci olgumuzda ise aynı protokolle fizyoterapi uygulanmasına rağmen geçen 14 ay zarfında hiçbir klinik düzelme sağlanamadı. MR incelemede nöral devamlılık teyit edildiği için cerrahi planlanmadı. Birinci yıl sonunda yapılan EMG incelemede ana peroneal sinirde ilerleyen total aksonal denervasyon saptandı. Hastamız emekliye ayrılarak işinden ayrıldı.

\section{Tartışma}

Dizin künt travmalarında ve ani varus travmalarında peroneal sinir arazı gelişebilmektedir. Travmanın erken evresinde göremediğimiz peroneal sinir arazı gibi bazı durumlar saatler ya da günler içinde gelişebilmektedir. Peroneal sinir arazı tedaviye rağmen kalıcı olabilmektedir. Peroneal sinir travması sonrası iyileşme süreci travma şiddeti ile ve hasta yaşı ile de alakalı olabilmektedir.

Ana peroneal sinir zedelenmesi sonrası en sık izlenen klinik tablo düşük ayaktır (1-5). Derin ve yüzeyel dalların travması ya da diğer bir

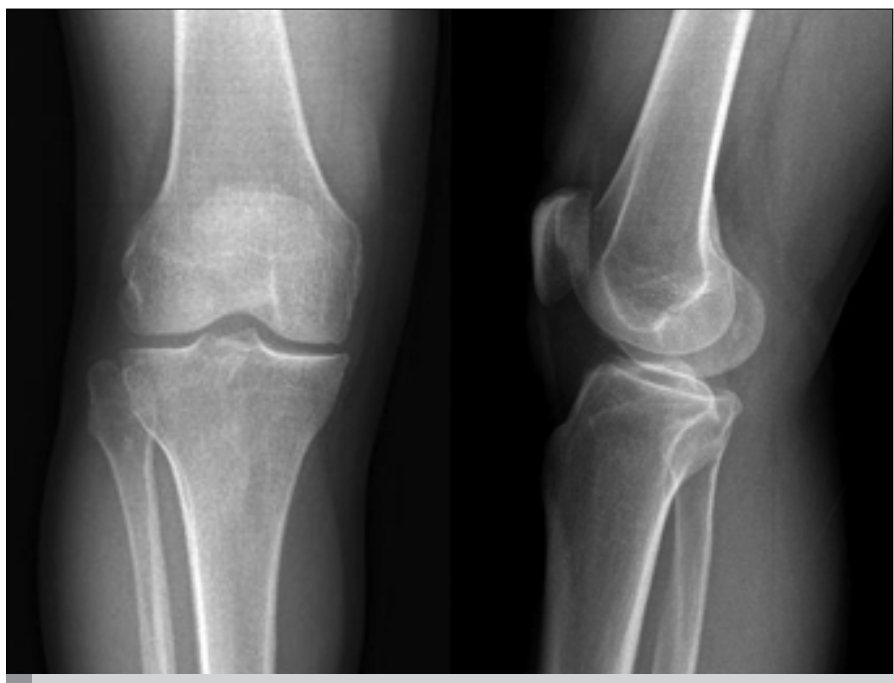

Resim 1. Hastanın travmadan hemen sonra çekilen direk radyografisinde herhengi bir patoloji dikkati çekmemektedir
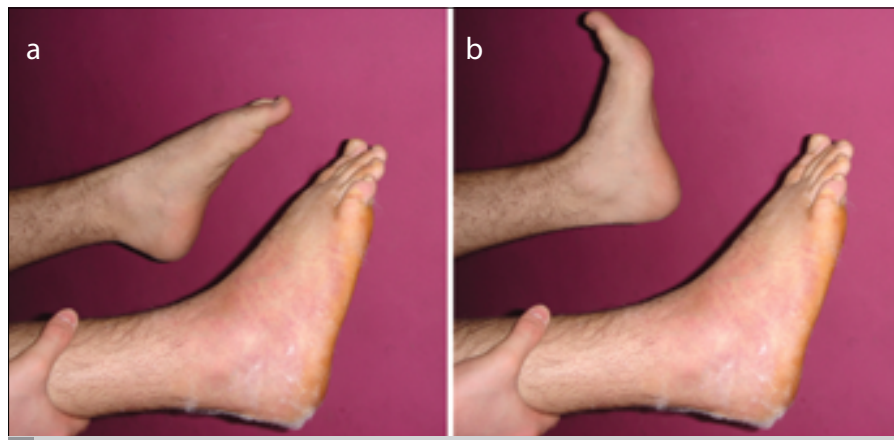

Resim 2. Aynı hastanın sol ayağının a. plantar ve b. dorsifleksiyonu varken, sağ ayağında dorsifleksiyon arazı geliştiği görüldü

deyişle ana peroneal sinirin yaralanması ayak bileği dorsifleksiyonunu sağlayan tibialis anterior ve peroneus tertius kasının inervasyon kaybına neden olmaktadır. Ayrıca ayak parmaklarının dorsifleksiyonunu sağlayan ekstansör digitorum brevis ve longus, ekstansör hallucis brevis ve longus kasları da etkisini kaybetmektedir. Ayak bileği evertörlerini inerve eden peroneus longus ve brevis kaslarının etkilenmesi ayak bileği inversiyon deformitesiyle sonuçlanır. Bu şekilde gelişen düşük ayak tablosunun bir sonucu olarak hastanın yürüyüşü bozulmakta ve zorlaşmaktadır. Derin dalın da etkilendiği tablolarda ayak birinci ve ikinci parmakları arasında duyu kaybı izlenebilir. İncelediğimiz olgularda günler sonra gelişen düşük ayak tablosu kliniği ana peroneal sinir hasarı ile uyumlu bulunmuş ve ilgili sinirin inerve ettiği kaslarda motor kayıp izlenmiştir.

Peroneal sinir travmaları gerilme ya da kontüzyon sonucu oluşabilen travmalardır $(1,2,3)$. Kontak sporlar ya da künt travmalar sonucu nöral hasar gelişebilmektedir $(1,5)$. Birinci olgumuzda peroneal araz dize gelen direk künt travma sonucu gelişirken ikinci olguda ani varus zorlaması yani gerilme sonucu gelişmiştir. Travma mekanizması hekimi tanı ve tedavi açısından yönlendirebilecek önemli bir detaydır. Künt travma sonrası herhangi bir osseöz patoloji saptanmasa dahi muhtemel yumuşak doku hasarı konusunda hekim dikkatli ol- 
malıdır. Travmaya uğrayan bölgedeki kas, tendon, vasküler ve nöral dokular göz önüne alınarak hasta değerlendirilmelidir.

Peroneal sinir hasarı en çok diz posterolateral köşesini ilgilendiren travmalar sonrası izlenmektedir (2). Aşırı gerilme sonrası sinir dokunun uğradığı hasar intranöral ya da ekstranöral skar formasyonu ile sonlanır. Ikinci olgumuzda da izlendiği gibi gerilme sonucu oluşan yumuşak doku hasarı ve fibrozis kalıcı sekel oluşturabilmektedir. Diz eklemi luksasyonları da \%25-36 peroneal sinir hasarına neden olan major travmalardan biridir (3). Eşlik eden posterolateral köşe yaralanması ve arka çapraz bağ yaralanması durumlarında peroneal hasar oranı \%45'lere kadar çıkabilmektedir $(3,4)$. Peroneal sinir hasarı olan vakaların \%16 kadarı proksimal tibia veya distal femur kırıkları ile ilişkilidir (5). Nöral hasar sonrası cerrahi gerekliliği konusunda farklı görüşler vardır. Birçok periferik sinir cerrahı operatif müdahale öncesi en az üç ay klinik takip önermektedir (2).

Ana peroneal siniri travmalara daha duyarlı hale getiren birçok faktör mevcuttur. Bu sinir fibula proksimalinden geçmekte ve nispeten daha az bir yumuşak doku örtüsü ile sarıldığından travmalara maruz kaldığında kolayca etkilenebilmektedir (2). Yine siyatik sinirin bir dalı olan tibial sinir posterior kompartmanda daha derin yerleşimli ve bol yumuşak doku ile örtülü olduğundan travmatik zedelenmesi çok daha nadirdir. Ana peroneal sinirin kemik üzerinde seyretmekle birlikte fikse bir pozisyonda olması kompresyon etkisini takiben yer değiştirme ihtimalini de azaltmaktadır.

\section{Sonuç}

Dizin künt travmalarında ve ani varus travmalarında peroneal sinir arazı gelişebilmektedir. Travmanın erken evresinde göremediğimiz peroneal sinir arazı gibi kemik dışı dokuları ilgilendiren durumlar saatler ya da günler içinde gelişebilmektedir. Peroneal sinir arazı tedaviye rağmen kalıcı olabilmektedir. Medikolegal açıdan hastalar olası problemler konusunda bilgilendirmeli ve düzenli kontrole çağırılmalıdır.

Conflict of Interest: No conflict of interest was declared by the authors.

Peer-review: Externally peer-reviewed.
Informed Consent: Written informed consent was obtained from patients who participated in this case.

Author Contributions: Concept - H.H.C.; Design - M.E.; Supervision I.T.; Funding - M.E.; Materials - K.B.; Data Collection and/or Processing - M.E., H.H.C.; Analysis and/or Interpretation - M.E., K.B.; Literature Review - H.H.C.; Writer - H.H.C.; Critical Review - I.T.

Financial Disclosure: The authors declared that this study has received no financial support.

Çıkar Çatışması: Yazarlar çıkar çatışması bildirmemişlerdir.

Hakem değerlendirmesi: Dış bağımsız.

Hasta Onamı: Yazılı hasta onamı bu olguya katılan hastalardan alınmıştır.

Yazar Katkıları: Fikir - H.H.C.; Tasarım - M.E.; Denetleme - I.T.; Kaynaklar - M.E.; Malzemeler - K.B.; Veri toplanması ve/veya işlemesi - M.E., H.H.C.; Analiz ve/veya yorum - M.E., K.B.; Literatür taraması - H.H.C.; Yazıyı yazan - H.H.C.; Eleştirel İnceleme - I.T.

Finansal Destek: Yazarlar bu çalışma için finansal destek almadıklarını beyan etmişlerdir.

\section{References}

1. Babwah TJ. Incidence of football injury during international tournaments. Res Sports Med 2009; 17: 61-9. [CrossRef]

2. Johnson ME, Foster L, DeLee JC. Neurologic and vascular injuries associated with knee ligament injuries. Am J Sports Med 2008; 36: 2448-62. [CrossRef]

3. Giuseffi SA, Bishop AT, Shin AY, Dahm DL, Stuart MJ, Levy BA. Surgical treatment of peroneal nerve palsy after knee dislocation. Knee Surg Sports Traumatol Arthrosc 2010; 18: 1583-86. [CrossRef]

4. Niall DM, Nutton RW, Keating JF. Palsy of the common peroneal nerve after traumatic dislocation of the knee. J Bone Joint Surg Br 2005; 87: 664-7. [CrossRef]

5. Krivickas LS, Wilbourn AJ. Peripheral nerve injuries in athletes: a case series of over 200 injuries. Semin Neurol 2000; 20: 225-32. [CrossRef] 